Digital Press Social Sciences and Humanities

Designing Mobile Application for Museum Enthusiasts

Dewi Puspasari

Proceeding of Indonesia Heritage Tourism Forum 2019 (IHTF 2019)

Dewi Pratika Ayu Dhira Pradati (eds) 


\title{
Designing Mobile Application for Museum Enthusiasts
}

\author{
Dewi Puspasari* \\ Universitas Indonesia, Jakarta, Indonesia \\ *e-mail: dewi.puspa00@gmail.com
}

\begin{abstract}
Until now, museums have not become a popular tourist destination in Indonesia. The number of visitors is relatively stagnant. Although on the other hand, the community that cares and loves museums start to grow. To lessen the old-fashioned impression of museum and to open up opportunities for the growth of new members who love and care about museums, this research proposes the design of mobile applications for museums. Feature requirements are obtained from open-questionnaires. Literature studies also become a benchmark for existing and similar applications. The design of this application mobiles utilizes use case diagrams.
\end{abstract}

\section{Keywords}

mobile application, museum enthusiast

\section{Introduction}

Museum became one of the attractions that is generally found in a large city. This tourist destination has its own attraction for visitors. Museums in general offer thematic collections, both those of a past nature and futuristic matters. The collection can also be in the form of the cultural and historical heritage of the city or things that are thematic in nature which are collections from various cities or countries. According to the International Council of Museums (ICOM), since 1946 museums can be defined as non-profit institutions that provide services to the public, are open to the public, which collects, preserve, research, communicate, and demonstrate humanity, both tangible and intangible. Museums are legacies for the purpose of education, learning, and having fun (International Council Of Museum, 2017). Recently it has a new definition, museum defined by ICOM as inclusive and polyphonic space for critical dialogue about things that have happened in the past and the future. The museum stores artifacts and specimens to preserve diverse memories for future generations and ensure equal rights and equal access to the inheritance for everyone (International Council of Museum, 2017). Meanwhile, based on Government Regulation of The Republic of Indonesia of 2015 Number 66 concerning the Museum, it is defined as an institution that has the function to protect, develop, utilize collections, and communicate them to the general public (Ministry of Law and Human Right of Republic Indonesia, 2015).

Although the museum has become one of the favorite tourist destinations in many countries, in Indonesia, visiting a museum and making it one of the tourist destinations are not yet common for most people. Growth in the number of tourists to the museum until now has not been significant, although since 2010 the Government took the initiative to launch the "National Museum of Love Movement". In 2014 the Government also launched the "Jingle Museum in My Heart" and "Museum in My Heart" programs, but the growth of tourists to the museum has not met expectations (Daranca \& Gunawijaya, 2015). In Jakarta, of the 64 museums, only 10 museums visited by tourists in 2016. The museum has not become a favorite tourist attraction because the museum is still considered a boring tourist attraction with a collection system that is boring, static, and events in the museum that are only formalities (Nuraeni, 2014).

However, behind the relatively stagnant number of museum visitors, communities began to grow in the fields of history and cultural heritage. They often visit museums and hold events at museums. Members of this community are those who care about the history, cultural heritage, and collections displayed in the museum. They make the museum as a means to learn and appreciate the cultural heritage. Communities like this that need to be appreciated and invited to work together. They can serve as an extension of the museum to promote collections and events in the museum, as well as foster a love of the museum, like a museum ambassador. 
Along with the development of digital technology, 'museum ambassadors' can also be in the form of mobile applications that are currently in high demand by the public, especially millennials and Generation $\mathrm{Z}$ (under 25 years). They are daily exposed to digital technology so they will easily get acquainted and adapt to mobile applications that contain things about museums in Indonesia (Republika, 2016). This mobile application in various developed countries already exists and is widely used by tourists, but in Indonesia, mobile applications in this field are very limited.

This mobile application can contain content provided by websites and social media managed by the museum, but also interesting features can be added. The museum's mobile application is expected to not only provide knowledge and insight, but also entertainment media and have an interaction function between users and the museum and their collections. This mobile application can use technological features that would be useful and entertaining. As a result, the research questions here are how to design a mobile application for museums to increase interaction between museums and the general public by observing the development of digital technology.

In this study, the authors contributed ideas for the development of mobile application designs about museums. The hope, if the design of this application is truly implemented as a mobile application, it will be able to increase involvement between the community and the museum, as well as open up opportunities for the growth of individuals who love and care about the museum. In addition, with the interesting features in this mobile application, the impression of the old and boring museum can be eroded slowly. Besides aiming to increase engagement between the museum and the community, this research also aims to provide input to museum managers in developing programs that attract tourists to visit.

In this paper the authors describe the background of the problem and the purpose of the study; then study literature that supports research; research methodology used; analysis and design that begins by benchmarking with the best comparison get similar applications and analyze the features proposed by respondents, to the application design process with use case diagram. Next, the author concludes at the end of the paper.

\section{Study of Literature}

Utilization of digital technology in helping to communicate information held to the museum has experienced growth, from what was originally a static website, then developed into a more interactive website and then continued with the addition of social media connected features. Each of these media, both static websites, interactive websites, and social media can still exist and be used together to complement each other in providing information as well as interactive communication media for museum lovers and the general public.

In this industrial era 4.0, digital technologies that have developed include augmented reality technology and virtual reality technology (Savitz, 2012). Both of these technologies are growing so rapidly and according to McLean (2005) an ideal museum exhibition is one that allows visitors to be able to interact with all the senses they have, so both of these technologies are starting to be widely applied in various modern museums in foreign countries. Visitors can get different experiences by using these features which can be accessed by android and iOS technology on their smartphones.

Augmented reality (AR) can be defined as a mixed reality or medium that combines real objects and places with virtual contents (Kounavis, Kasimati, \& Zamani, 2012; Rhodes, 2015). A system can be called implementing an AR system if it meets the following three things, namely combining real and virtual objects in a real environment; aligning real and virtual objects with each other; and walk interactively (Kounavis et al., 2012). The technology had been applied in education, simulation training, health, and medical, also in the entertainment field.

Meanwhile, virtual reality (VR) can be defined as technology that can provide the ability to create a work environment that seems real. Virtual reality can lead us to a world of destinations that look exactly the same as our own (van Krevelen, 2007). However, this technology also has limitations. The limitation included the user being in a simulated environment, completely as if separated from the real world, and to get this experience a smartphone that has advanced specifications and connections is needed (Chen, Chang, \& Huang, 2014; Kounavis et al., 2012). In addition, to be able to use virtual reality technology users also need special additional tools that are not cheap (Havig, McIntire, \& Geiselman, 2011).

In addition to these two technologies, there are many mobile applications that add proximity features with Wireless Sensor Networks (Kuriakose, Joshi, Vikram Raju, \& Kilaru, 2014). The goal is to find out the current location and find out what buildings or services are nearby. By turning on this feature, including 
the GPS feature, users can find the location of supermarkets, places to eat, cinemas, and so on that are close to their location.

Meanwhile, in developing an application, some developers use the use case diagrams. The use case diagram is widely used by developers to describe the functions in a system and its relationship with access rights by each user (Dijkman, Joosten, \& Utopics, 2002). The use case diagram is part of the Unified Modeling Language (UML). The functions of the diagram are to describe and to design a feature in a system, and to explain the behavior in a system. In use case diagram, the interaction between actors or users and features in the system is seen (Dijkman et al., 2002).

\section{Research Methodology}

The methodology of developing a museum mobile application through a series of stages. The activities carried out can be seen in the figure below.

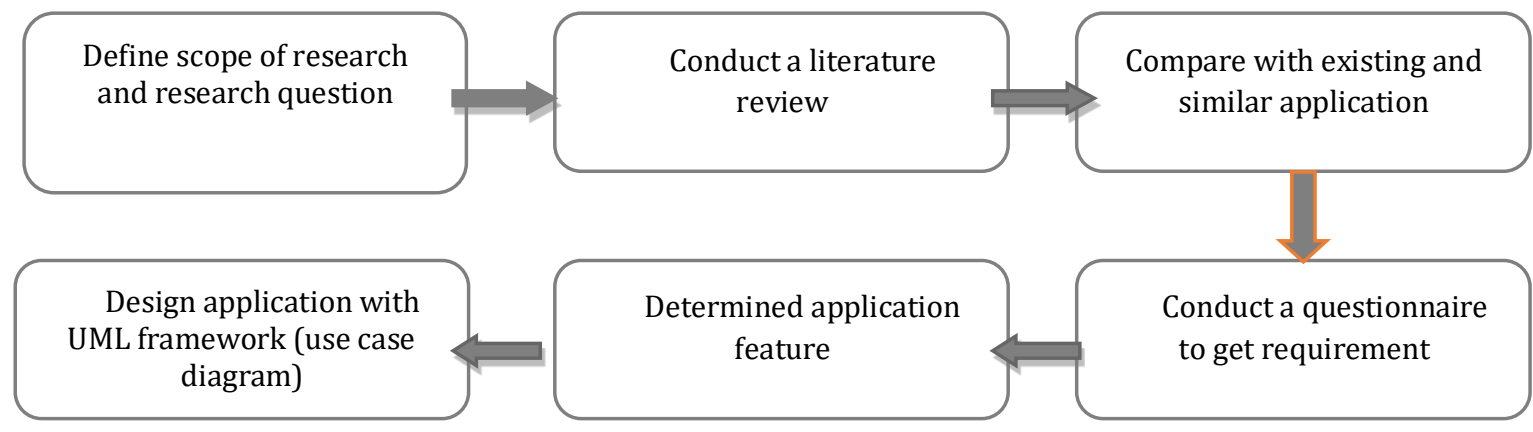

Fig. 1 Research Stage

The sequence of stages are as follows:

1. This research began by doing observation to define the scope of research and the problem's formulation. The main problem is how to increase public engagement to the museums by using digital technology, in this case, mobile technology and technology developing today, such as virtual reality and augmented reality. The scope of research is making a mobile application about museums in Indonesia, with a pilot project in Jakarta, followed by other regions.

2. The research continues with the study of literature on the development of digital technology in the field of museums both conducted by local and foreign researchers,

3. Furthermore, the authors analyze the mobile application about museums that already exist in Indonesia and abroad today and similar mobile applications. The author also observed the behavior of SIJI mobile application users, who used it at the Proclamation Text Formulation Museum, Jakarta.

4. The author then identifies museum features that would be needed in the form of a mobile application by conducting an open questionnaire to 10 respondents representing groups who are often to go to the museum and who rarely to go to the museum.

5. Based on the results of the questionnaire and the literature and benchmark mobile applications that already exist or similar, the writer then defines the domain, each process flow domain. This we summarized as application architecture.

6. Then the author detailed the application architecture into application features

7. Features of the process, users who are involved in each process then we have described in UML syntax, consist of use case diagrams and use case scenarios. The authors chose UML for modeling because UML has several benefits, well documented, easier visualization, simplify the management of complexity, and clarifies the communication in software development. 


\section{Analysis and Design}

This analysis and design chapter begins with a benchmark of existing mobile application applications and similar mobile applications, then analyzes the features based on the results of the questionnaire.

\subsection{Benchmark Existing and Similar Application}

Augmented reality technology and proximity detected began to be widely applied in modern museums. Visitors can get a different experience by using these features which can be accessed by android and IOS technology on their smartphones. Virtual reality features also been used in The Musée d'Orsay in some collections. In this case, the author uses several examples of foreign museum applications that already exist.

Table 1 Some Examples of Existing Foreign Museum Mobile Applications

\begin{tabular}{|c|c|c|c|c|c|c|c|}
\hline Features & $\begin{array}{l}\text { Guggenheim } \\
\text { Museum }\end{array}$ & $\begin{array}{l}\text { The J. Paul } \\
\text { Getty } \\
\text { Museum }\end{array}$ & $\begin{array}{l}\text { Amsterdam State } \\
\text { Museum (The } \\
\text { Rijksmuseum) }\end{array}$ & $\begin{array}{l}\text { The Musée } \\
\text { d'Orsay }\end{array}$ & $\begin{array}{l}\text { British } \\
\text { Museum } \\
\text { Visitor } \\
\text { Guide }\end{array}$ & $\begin{array}{l}\text { Heritage App } \\
\text { (Hera) }\end{array}$ & $\begin{array}{c}\text { Adiante } \\
\text { App }\end{array}$ \\
\hline $\begin{array}{c}\text { Display } \\
\text { Information }\end{array}$ & $\begin{array}{l}\text { Display photos } \\
\text { of museum } \\
\text { buildings, } \\
\text { museum } \\
\text { collections, and } \\
\text { exhibitions that } \\
\text { are currently } \\
\text { underway. }\end{array}$ & $\begin{array}{l}\text { Display } \\
\text { exhibition, } \\
\text { collections, } \\
\text { event }\end{array}$ & $\begin{array}{l}\text { Display collections, } \\
\text { interactive map of } \\
\text { the museum }\end{array}$ & $\begin{array}{l}\text { Display } \\
\text { collections, } \\
\text { interactive } \\
\text { map of the } \\
\text { museum }\end{array}$ & $\begin{array}{l}\text { Display } \\
\text { collections, } \\
\text { interactive } \\
\text { map of the } \\
\text { museum }\end{array}$ & $\begin{array}{l}\text { Display } \\
\text { collections, } \\
\text { catalog }\end{array}$ & $\begin{array}{l}\text { Display } \\
\text { temporary } \\
\text { exhibition } \\
\text { and offers, } \\
\text { opening } \\
\text { times }\end{array}$ \\
\hline $\begin{array}{c}\text { Add } \\
\text { Experience } \\
(\mathrm{AR}, \mathrm{VR}, \mathrm{etc})\end{array}$ & $\begin{array}{l}\text { AR for } \\
\text { enhancing the } \\
\text { experience, } \\
\text { provide video }\end{array}$ & - & Take a visual tour & $\begin{array}{c}\text { VR in } \\
\text { Egyptian } \\
\text { Galleries - } \\
\text { with device }\end{array}$ & $\begin{array}{c}\text { Take a visual } \\
\text { tour }\end{array}$ & $\begin{array}{l}\text { Multimedia } \\
\text { resources }\end{array}$ & $\begin{array}{c}\text { Provide } \\
\text { audio \& } \\
\text { video guide }\end{array}$ \\
\hline Proximity & $\begin{array}{l}\text { Provide metro } \\
\text { maps }\end{array}$ & $\begin{array}{l}\text { Indoor } \\
\text { navigation and } \\
\text { metro maps } \\
\text { (premium) }\end{array}$ & Indoor navigation & $\begin{array}{l}\text { Indoor } \\
\text { navigation }\end{array}$ & $\begin{array}{l}\text { Indoor } \\
\text { navigation }\end{array}$ & $\begin{array}{c}\text { Indoor } \\
\text { navigation, } \\
\text { environment, } \\
\text { and } \\
\text { monitoring }\end{array}$ & $\begin{array}{l}\text { Guide the } \\
\text { visitors with } \\
\text { GPS to the } \\
\text { locations of } \\
\text { the museum }\end{array}$ \\
\hline $\begin{array}{c}\text { Other } \\
\text { Features }\end{array}$ & $\begin{array}{l}\text { Multilingual, } \\
\text { search tour, } \\
\text { verbal } \\
\text { description } \\
\text { guide }\end{array}$ & - & Buy ticket & $\begin{array}{l}\text { Give and read } \\
\text { reviews, } \\
\text { search and } \\
\text { book tour }\end{array}$ & $\begin{array}{l}\text { Bilingual: } \\
\text { French and } \\
\text { English }\end{array}$ & Multilingual & $\begin{array}{l}\text { Sell ticket, } \\
\text { integrate } \\
\text { social } \\
\text { networks }\end{array}$ \\
\hline
\end{tabular}

Museums such as the Amsterdam State Museum (The Rijksmuseum) display their collections, complete with historical and video details so that those who are at home are as if walking around on a tour of the museum. While with the Adiante app, visitors can buy the ticket by online method. The visitor also can share their experiences with social networks.

In Indonesia, the existing museum mobile application is the SIJI application, which is an application based on augmented reality. SIJI application can transform images into digital experiences. Users only need to scan the panel marked with SIJI, then the system will respond by displaying a short video. One of these SIJI applications has been used at the Museum of Proclamation Text Formulation in Central Jakarta. Other existing applications are entertainment and tourism application mobile that the concept can be adopted in the proposed museum mobile application are the Recome and Tripadvisor application mobiles. From both applications, the user can get a lot of information, namely things about entertainment places in Recome and tourism on Tripadvisor. 
Table 2 Mobile Application Relating to Entertainment and Travel

\begin{tabular}{|c|c|c|c|}
\hline & Name & RecoMe & Tripadvisor \\
\hline & Goals & Application for everything related to entertainment & $\begin{array}{l}\text { Application for everything related to travel and } \\
\text { tourism }\end{array}$ \\
\hline \multicolumn{4}{|c|}{ Features } \\
\hline a. & $\begin{array}{l}\text { Display } \\
\text { Information }\end{array}$ & $\begin{array}{l}\text { Provides information about films, theaters, dining } \\
\text { venues, beauty care venues, and entertainment \& } \\
\text { relaxation venues; provide reviews and photos/videos of } \\
\text { theirs }\end{array}$ & $\begin{array}{l}\text { Provides information about hotels, flights, } \\
\text { f restaurants, and other attractions }\end{array}$ \\
\hline b. & Searching & Find a restaurant, a place for treatment, as appropriate & $\begin{array}{l}\text { Find restaurants/attractions/hotels easily; } \\
\text { search and book tours }\end{array}$ \\
\hline c. & $\begin{array}{l}\text { Give/read } \\
\text { review }\end{array}$ & $\begin{array}{l}\text { Give or read the reviews of other Recome users and view } \\
\text { shared photos/videos }\end{array}$ & $\begin{array}{l}\text { Give or read traveler reviews and see } \\
\text { photos/videos shared }\end{array}$ \\
\hline d. & Get Point & Earn points for activities carried out & Earn points for activities carried out \\
\hline e. & Badge & Give badges based on the user level & Give badges based on the user level \\
\hline f. & Prize & Can exchange points for prizes; choose the desired gift & $\begin{array}{l}\text { Depends on (sometimes cooperate with Garuda } \\
\text { Airways Indonesia) }\end{array}$ \\
\hline g. & Proximity & Provide recommendations on places closest to the user & $\begin{array}{l}\text { Provide recommendations on places closest to } \\
\text { the user }\end{array}$ \\
\hline h. & Others & Integrate social networks & $\begin{array}{l}\text { View hotel offers from various booking sites; } \\
\text { follow friends and travel experts for specific } \\
\text { advice }\end{array}$ \\
\hline
\end{tabular}

\subsection{Features Expected from Questionary Result}

The author has collected the features expected by the user. Respondents were chosen randomly, representing three groups, namely those who rarely visited the museum (frequency of arrival $<5$ times), namely 5 people, enough (frequency $>5$ times but $<10$ times), namely 2 people and frequently (frequency of arrival> 10 times) namely 3 people. The expected features of this mobile application can be seen in the table below.

Table 3 Features Expected from Mobile Application of Museum from Questionary Result

\begin{aligned} & \hline No \\ & \hline 1 Display the tour schedule \& guide \\ & 2 There is a notification of something new in the museum \\ & 3 Display events at the museum \\ & 4 Display interactive information \\ & 5 Display points of interest \\ & 6 Order tickets online \\ & 7 Display the directory of museums in Indonesia \\ & 8 Display an interactive map of the museum \\ & 9 Can find out the museum in the closest location to the user \\ & 10 There is an interesting quiz \\ & 11 Display detailed information about the museum, operating hours, ticket prices, and others \\ & 12 Displays museum collection information \\ & 13 Featuring a trailer for the museum documentary video collection \\ & 14 Augmented reality feature for enhancing experience \\ & \hline\end{aligned}




\subsection{Design of Museum Mobile Application}

Based on questionnaires, literature studies, and also by benchmarking existing and similar applications, the following functions and features of mobile apps will be designed. However, based on interviews conducted with museum officials, there is a limitation to the museum application mobile features. The museum official required that visitors arrive and enjoy the experience by being present directly at the museum. Consequently, the authors propose the following features. The following features can be seen in Table 4.

Table 4 Features of Museum Mobile Application

\begin{tabular}{|c|c|c|}
\hline Functions & No & Features \\
\hline \multirow[t]{7}{*}{ Display information } & 1 & Display the directory of museums in Indonesia \\
\hline & 2 & $\begin{array}{l}\text { Display detailed information about the museum: history, days and } \\
\text { hours of operation, ticket prices, and others }\end{array}$ \\
\hline & 3 & Provide an overview of museum collections \\
\hline & 4 & Display current events at the museum \\
\hline & 5 & Know the museum tour schedule \\
\hline & 6 & Display photos and videos of museum buildings \\
\hline & 7 & Display photos and trailer videos of the museum collection \\
\hline \multirow[t]{2}{*}{ Book ticket } & 8 & Make museum ticket reservations and get digital tickets \\
\hline & 9 & Book tour/event tickets at the museum and get digital tickets \\
\hline \multirow{3}{*}{$\begin{array}{l}\text { Proximity and } \\
\text { interactive map }\end{array}$} & 10 & Find out the closest museum to the user's location \\
\hline & 11 & $\begin{array}{l}\text { Display the location of the nearest museum in the form of a map and } \\
\text { estimates arrive }\end{array}$ \\
\hline & 12 & $\begin{array}{l}\text { Display an interactive map of the museum when it arrives at the mu- } \\
\text { seum }\end{array}$ \\
\hline \multirow[t]{5}{*}{ Sharing experiences } & 13 & Provide reviews accompanied by photos/videos \\
\hline & 14 & Share reviews via social media \\
\hline & 15 & Read other user reviews \\
\hline & 16 & Give a 'like' and comments to other user reviews \\
\hline & 17 & Do a 'check in' to the museum \\
\hline \multirow{5}{*}{$\begin{array}{l}\text { User points and } \\
\text { ranking }\end{array}$} & 18 & Get points for activities carried out (check in and leave a review) \\
\hline & 19 & Collect points through quiz or game \\
\hline & 20 & Exchange points for prizes based on the number of points collected \\
\hline & 21 & Display user level based on points \\
\hline & 22 & Get special badges based on user level \\
\hline \multirow[t]{4}{*}{ Give more experience } & 23 & Provide a digital experience with users scanning (augmented reality) \\
\hline & 24 & Provide a virtual tour experience with several collections \\
\hline & 25 & $\begin{array}{l}\text { Give notifications about events to be held or the existence of the clos- } \\
\text { est museum to the location }\end{array}$ \\
\hline & 26 & $\begin{array}{l}\text { Give notifications about the existence of the closest museum to the lo- } \\
\text { cation }\end{array}$ \\
\hline
\end{tabular}

This system is used by several users called actors, actors including application users (users), admin of museums namely museum official representatives, and system administrators. Because the active user of this system is a user, he/she can do many processes except the process of changing and adding information from each feature, such as adding or changing detailed information about the museum: history, days and hours of operation, ticket prices, and others; approve payment of tickets, and so on. While the system admin is related to the approval process or if there is a problem in terms of registration. Broadly speaking, the relationship between actors and functions can be seen in the use case diagram of the zero level as in the following figure. 


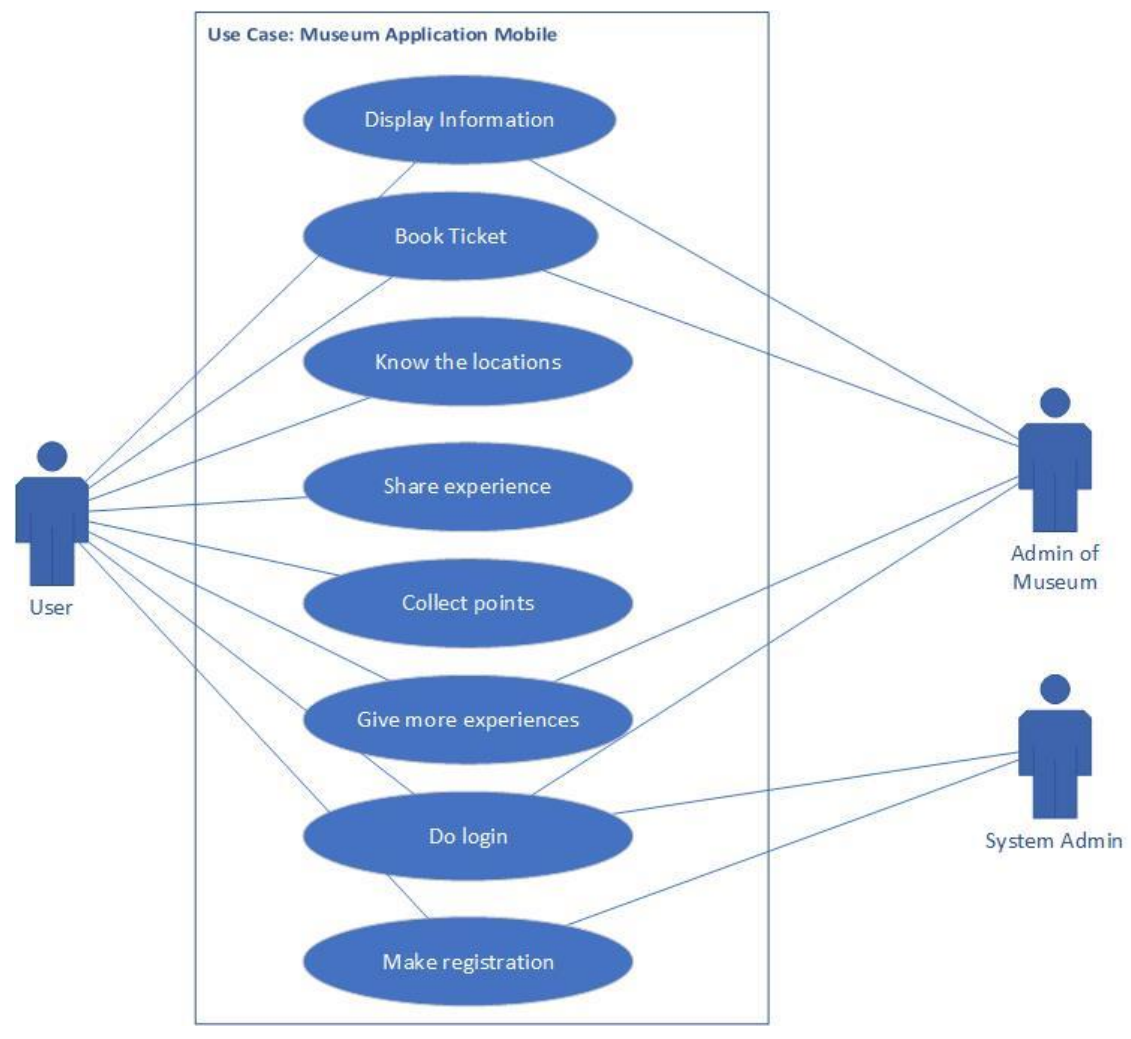

Fig. 2 Use Case Diagram 0 of Museum Application Features

Based on Fig. 2, it can be seen that users can use application functions related to login, display information, book tickets, know the locations, share experiences, collect points, give more experiences, do logins, and make registration. While, the admin of the museum has to do with the function to add and change information displays, book tickets, and give more experiences by logging in first. Whereas the system admin can $\log$ in and handle user registration problems

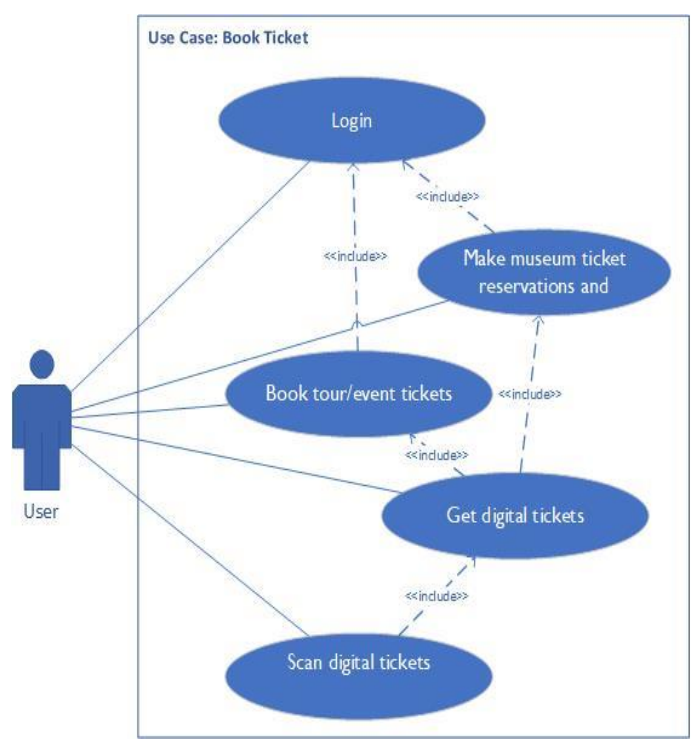

Fig. 3 Use Case Diagram of Book Ticket

More details about the ticket booking process can be seen in Fig. 3. Users after logging in can order museum tickets or order a tour /even museum until the payment process. After that, he will get a digital ticket. Upon entering the museum, they will scan the ticket. Another example of a use case diagram is the process of collecting points from activities, then the user after logging in can collect points from quizzes, games, and other activities. Then he can exchange points with prizes and also display user level based on points. 


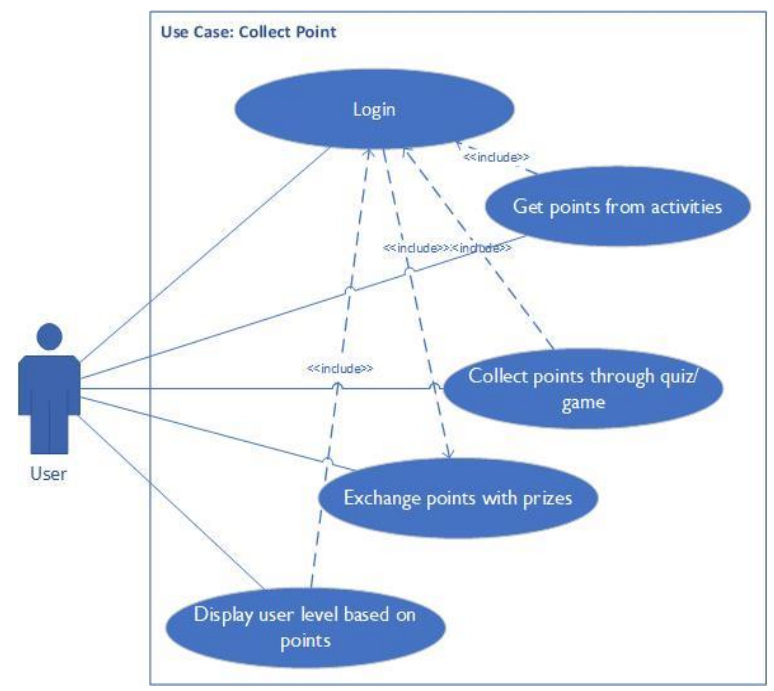

Fig. 4 Use Case Diagram of Collect Point

The example of the interface design of the museum mobile application can be seen in Fig. 5. On the front page on the left corner, there are regional locations, for example, the city of Malang. At the top, there is a search feature and a bell icon for notifications. The main picture shows the museum in the city, for example, the Brawijaya Museum in Malang. The director shows a list of museums in the city of Malang. Two other features in line with the 'directory' are 'gallery' and 'ticket/tour booking'. The center feature shows 'recent collections', 'video collections' and recent articles', and' lists of events and activities'. At the very bottom, there is a 'Me' feature to show account profiles, badges, messages, and so on. At the bottom center, there is 'SIJI' to get an augmented reality experience. While in the bottom corner is 'around' to find out things around. This design can still be changed based on your needs and preferences.

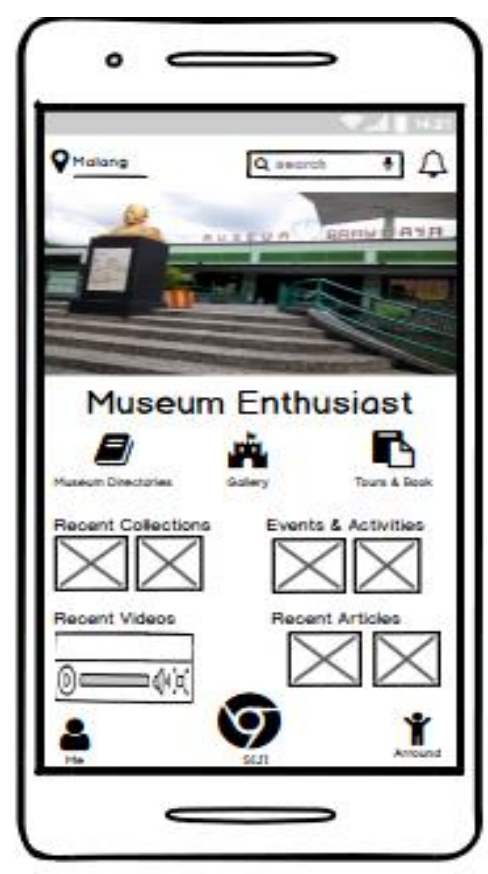

Fig. 5 Application Interface Design 


\section{Conclusion}

At this time the community, especially millennial generation is very close to the use of applications in mobile phones. This has become an opportunity for museum managers to use museum applications to increase public interest and to enhance engagement. Museum applications can also provide more experience to visitors. In this study, the author proposes mobile apps for the museum by adding features such as augmented reality, proximity, reviews, social networks, collect points, book tickets, and so on. This research is still in the beginning, needs further study by involving key users and museum representatives to get more complete requirements.

\section{References}

Chen, C. Y., Chang, B. R., \& Huang, P. S. (2014). Multimedia augmented reality information system for museum guidance Pers. Ubiquitous Comput., 18(2), 315-322. Retrieved from https://doi.org/10.1007/s00779-0130647-1

Daranca, U., \& Gunawijaya, J. (2015). Strategi Pengembangan Museum Nasional Indonesia sebagai Upaya Peningkatan Wisata di Jakarta. Retrieved from http://lib.ui.ac.id/naskahringkas/2018-11/S59609-Unira

Dijkman, R. M., Joosten, S. M., \& Utopics, O. F. (2002). An algorithm to derive use case diagrams from business process models. Proc. of the 6th Intern. Conf. on Software Engineering and Applications (SEA), 679-684. Anaheim, US.

Havig, P., McIntire, J., \& Geiselman, E. (2011). Virtual reality in a cave: limitations and the need for HMDs? In P. L. Marasco \& P. R. Havig (Eds.), Proceedings of SPIE - The International Society for Optical Engineering (p. 804107). https://doi.org/10.1117/12.883855

International Council Of Museum. (2017). Creating a New Museum Definition -- the Backbone of International Council of Museum, Paris. Retrieved from https://icom.museum/en/standards-guidelines/museumdefinition/

Kounavis, C. D., Kasimati, A. E., \& Zamani, E. D. (2012). Enhancing the Tourism Experience through Mobile Augmented Reality: Challenges and Prospects. International Journal of Engineering Business Management, 4, 1-6. Retrieved from https://doi.org/10.5772/51644

Kuriakose, J., Joshi, S., Vikram Raju, R., \& Kilaru, A. (2014). A Review on Localization in Wireless Sensor Networks. In A. Gelbukh \& J. Mukhopadhyay (Eds.), Thampi S (pp. 599-610). https://doi.org/10.1007/9783-319-04960-1_52

McLean, F. (2005). Museum and National Identity. Museum and Society, 3(1), 1-4.

Ministry of Law and Human Right of Republic Indonesia. (2015). Government Regulation of The Republic of Indonesia of 2015 Number 66 concerning the Museum. Retrieved from https://peraturan.bpk.go.id/Home/Details/5642

Nuraeni, B. S. (2014). Analisis Faktor-faktor yang Mempengaruhi Minat Kunjung Ulang Wisatawan Museum Ranggawarsita Semarang. Jurnal Bisnis Dan Strategi, 23(1), 1-20. Retrieved from https://doi.org/10.14710/jbs.23.1.1-20

Republika. (2016). Mengenal Generasi Milenial. Retrieved from Republika. Website: Retrieved from https://www.republika.co.id/berita/koran/inovasi/16/12/26/ois64613-mengenal-generasi-millennial

Rhodes, A. G. (2015). Future Museums Now -- Augmented Reality Musings. Public Art Dialogue, 5(1), 59-79. Retrieved from https://doi.org/10.1080/21502552.2015.1010839 
Savitz, E. (2012). Gartner: Top 10 Strategic Technology Trends for 2013. Retrieved from Forbes website: https://www.forbes.com/sites/ericsavitz/2012/10/23/gartner-top-10-strategic-technology-trends-for2013/\#6e6e6e1bb761

van Krevelen, D. W. F. (2007). Augmented Reality: Technologies, Applications, and Limitations. Retrieved from https:/www.researchgate.net/profile/Rick_Van_Krevelen2/publication/292150312_Augmented_Reality_ Technologies_Applications_and_Limitations/links/56ab2b4108aed5a01359c113/Augmented-RealityTechnologies-Applications-and-Limitations.pdf 